\title{
XPS Analysis of Passive Film on Stainless Steel
}

\author{
R. Natarajan ${ }^{1}$, N. Palaniswamy ${ }^{2}$, M. Natesan ${ }^{*}, 2$ and V.S. Muralidharan ${ }^{3}$ \\ ${ }^{1}$ Alagappa Government Arts College, Karaikudi, TN, India-630003 \\ ${ }^{2}$ Corrosion Science \& Engineering Division, Central Electrochemical Research Institute, Karaikudi, TN, 630006, India \\ ${ }^{3}$ Alagappa Chettiar College of Engineering and Technology, Karaikudi, TN, 630004, India
}

\begin{abstract}
Potentiodynamic, impedance measurements were carried out on 304 stainless steel in $0.5 \mathrm{~N}, 1.0,2.0$ and $5.0 \mathrm{~N}$ $\mathrm{H}_{2} \mathrm{SO}_{4}$ solutions. X-ray photoelectron spectroscopic [XPS] studies carried out on 304 stainless steel in $\mathrm{H}_{2} \mathrm{SO}_{4}$ solutions revealed the existence of $\mathrm{CrOOH}, \mathrm{Cr}_{2} \mathrm{O}_{3}, \gamma-\mathrm{Fe}_{2} \mathrm{O}_{3}, \gamma-\mathrm{FeOOH}, \mathrm{Mn}_{2} \mathrm{O}_{3}, \mathrm{Mn}_{3} \mathrm{O}_{4}, \mathrm{MnS}, \mathrm{Ni}(\mathrm{OH})_{2}, \mathrm{Ni}_{2} \mathrm{O}_{3}, \mathrm{NiO}$, sulphides. The passive film found to contain chromium oxide inner layer and the dissolution of iron through it caused the formation of oxides of iron namely $\gamma-\mathrm{Fe}_{2} \mathrm{O}_{3}$ and $\gamma$-FeOOH. Higher oxides of manganese and nickel are also due to dissolution through the film. Sulphates are reduced to sulphur chemically by the released protons from anodic polarization.
\end{abstract}

Keywords: 304 stainless steel, passive film, impedance method, polarization, XPS studies.

\section{INTRODUCTION}

Kier [1] published the first report on the passivity of iron in 1790. In 1925 active-passive behaviour on iron in $60 \%$ $\mathrm{HNO}_{3}$ was demonstrated [2]. The passive film on iron was found to be not an insulator by Faraday [3]. In 1939 passivation of stainless steel was discussed using electronic configuration [4]. Passive state and dissolution were found to be independent of surface film [5]. Ellipsometric studies on $18 / 8$ stainless steel revealed the existence of oxide on iron and found air formed oxide was replaced by a thicker and denser oxide. On progressive anodic polarization, metal form multilayer oxide films with increase in thickness [6]. Hackerman [7] proposed a model for the growth of oxide from initially adsorbed oxygen. In stainless steel, the presence of chromium is responsible for passivation [8], nickel stabilizes austenitic structure [9] and Molybdenum prevents depassivation by pitting [10].

Steel tanks are being used to transport and store sulphuric acids. However for longer storage of time the steel tanks are anodically protected. For transportation of higher concentrations of sulphuric acids stainless steel lined or stainless steel containers are used as the surface become passivated. The present investigation aims at the understanding of the composition of passive film formed on 304 - stainless steel in $\mathrm{H}_{2}$ $\mathrm{SO}_{4}$ solutions in the primary passive and secondary passive region.

\section{MATERIALS AND METHODOLOGY}

304 stainless steel rod encapsulated in Teflon with $0.5 \mathrm{~cm}$ diameter was used as the working electrode for electrochemical studies. The surface of the electrode was polished to mirror finish using SiC emery paper (1/0 to 4/0) degreased with acetone and finally rinsed with triple distilled water. For

*Address correspondence to this author at the Corrosion Science \& Engineering Division, Central Electrochemical Research Institute, Karaikudi, TN, 630006, India; Tel: 91-(04565) 227550-9; Fax; (04565) 227713/ 227779; E-mail: mnatesan@rediffmail.com
XPS studies one sq. cm surfaces were exposed and and analar grade chemicals were used.

Potentiodynamic anodic polarization study was carried out using EG \& G Princeton Applied Research (PAR) model 173 potentiostat with EG \& G PAR model 175 programmer connected to RiKadenky $\mathrm{x}-\mathrm{y}$ recorder. The electrochemical cell having a capacity of $200 \mathrm{ml}$ with provision for gas inlet, working electrode, counter electrode (Platinum foil having $2 \mathrm{~cm}^{2}$ area connected with platinum wire dipped in mercury contact through copper wire) and salt bridge were used. The potential of the working electrode was measured with respect to saturated calomel electrode [SCE] which was connected through a salt bridge. After 15 minutes, the IR compensation was done and the experiment was carried out. The scanning potential range was from $-500 \mathrm{mV}$ to $800 \mathrm{mV} v s$ SCE at a scan rate of $1 \mathrm{mV} / \mathrm{sec}$. Potential was plotted against log current.

Alternating current impedance measurements were carried out by using computer controlled EG\&G PAR Model 6310 electrochemical impedance analyzer. The experimental setup was the same as for potentiostatic method. At different preselected potentials, impedance diagrams were obtained. The frequency ranged from $100 \mathrm{mHz}$ to $10 \mathrm{kHz}$. From the Bode plots $(\log |\mathrm{z}| v s \log \mathrm{w})$, the charge transfer resistance) $\left(R_{c t}\right)$ and solution resistances $\left(R_{s}\right)$ were calculated. The double layer capacitance $\left(\mathrm{C}_{\mathrm{dl}}\right)$ were calculated from the equation

$\mathrm{C}_{\mathrm{dl}}=1 / 2 \pi \mathrm{f}_{\max } \mathrm{R}_{\mathrm{ct}}$

where, $f_{\max }$ is the maximum frequency obtained in the $\mathrm{Ny}$ quist plots.

The chemical composition of the passive film formed on the surface was analysed by using VG scientific mark II ESCA Spectrometer. The film was formed on the surface by keeping the specimen for about an hour in the primary passivation range potential and in secondary passivation range potential in $0.5 \mathrm{~N}$ and $5.0 \mathrm{~N} \mathrm{H}_{2} \mathrm{SO}_{4}$ solutions. The surface was dried and examined. In order to investigate the nature and valencies of the constituent's elements in the film the specimen was analyzed by means of XPS $\mathrm{MgK}_{\alpha}$ irradiation with a 
mean energy of $1253.6 \mathrm{eV}$. The voltage and current applied to the $\mathrm{x}$-ray tube were $8 \mathrm{kV}$ and $100 \mathrm{~mA}$ respectively. The specimen container was evacuated to $10^{-9} \mathrm{~m}$ bar. $\mathrm{C}_{\mathrm{IS}}$ binding energy, $285 \mathrm{eV}$ of hydrocarbon contamination was used as calibration to compensate the charging system. A delocalized $\mathrm{Ar}^{+}$ion beam accelerated under $2 \mathrm{KeV}$ was used to remove adsorbed contaminants on the surfaces. The photoelectron as spectra of Fe 2p, Cr 2p, Ni 2P, Mn 2p, S 2p, O 2p electron levels are measured.

\section{RESULTS}

Potentiostatic anodic polarization studies were carried out on stainless steel in various concentrations of $\mathrm{H}_{2} \mathrm{SO}_{4}$ solutions (Fig. 1). Open circuit potential (OCP) became noble with the concentration of $\mathrm{H}_{2} \mathrm{SO}_{4}$. When polarized anodically, current started increasing upto $-370 \mathrm{mV}$ in $0.5 \mathrm{~N} \mathrm{H}_{2} \mathrm{SO}_{4}$ solutions $\left(\mathrm{E}_{\text {critical }}\right)$. This potential was nearly invariant for all concentrations of $\mathrm{H}_{2} \mathrm{SO}_{4}$ (Table 1). Further polarization decreased the current due to the formation of passive film. The primary passivation of the surface occurred in the potential range of $200 \mathrm{mV}$ to $0 \mathrm{mV}$. Beyond $0 \mathrm{mV}$, current started rising till the potential reached $50 \mathrm{mV}$. Further anodic polarization caused a secondary passivation. Beyond $350 \mathrm{mV}$, current started increasing due to oxygen evolution. Increase of concentration of the acid increased critical current $\left(i_{\text {crit }}\right)$, primary passivation current $\left(i_{\mathrm{p} . \mathrm{p}}\right)$ and secondary passivation current $\left(\mathrm{i}_{\mathrm{s} . \mathrm{p}}\right)$.



Fig. (1). Anodic polarization curve for stainless steel in various concentrations of $\mathrm{H}_{2} \mathrm{SO}_{4}$ solutions.

\subsection{Open Circuit Potential Region}

At the open circuit potential, impedance measurements were made. The obtained Bode plots (Fig. 2) revealed that the shapes of curves are similar. The charge transfer resistances, solution resistances and double layer capacitances were calculated (Table 2). Charge transfer resistances decreased and double layer capacitance $\left(\mathrm{C}_{\mathrm{dl}}\right)$ increased with the concentration of $\mathrm{H}_{2} \mathrm{SO}_{4}$.

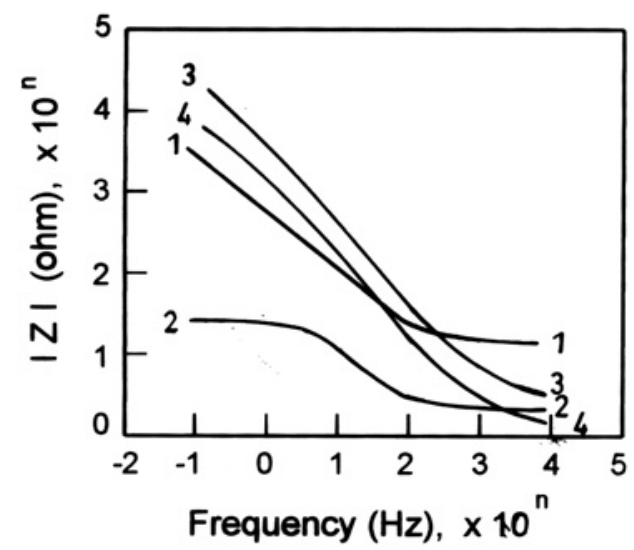

Fig. (2). Bode plots obtained for stainless steel in various concentrations of $\mathrm{H}_{2} \mathrm{SO}_{4}$ solutions at the open circuit potential region $(-450 \mathrm{mV})$.

Table 2. Parameters Derived from Impedance Diagrams for Various Concentrations of $\mathrm{H}_{2} \mathrm{SO}_{4}$ at the Open Circuit Potential

\begin{tabular}{|c|c|c|}
\hline $\begin{array}{c}\text { Concentration } \\
\text { of } \mathbf{H}_{2} \mathbf{S O}_{4} \\
\text { (Normality) }\end{array}$ & $\begin{array}{c}\text { Charge Transfer } \\
\text { Resistance } \\
\text { k. ohm/.cm }\end{array}$ & $\begin{array}{c}\text { Double Layer } \\
\text { Capacitance } \\
\text { F/cm }^{2} \mathbf{x} \mathbf{~ 1 0}^{-4}\end{array}$ \\
\hline \hline 0.5 & 24.74 & 2.17 \\
\hline 1.0 & 21.16 & 6.39 \\
\hline 2.0 & 7.33 & 7.54 \\
\hline 5.0 & 2.19 & 16.3 \\
\hline
\end{tabular}

\subsection{Active Dissolution Region}

Fig. (3) presents the Bode plots obtained in various concentrations of $\mathrm{H}_{2} \mathrm{SO}_{4}$ at $-400 \mathrm{mV}$. The curves exhibited longer horizontal regions at lower frequencies suggesting the absence of a passive film. Increase of acid concentration decreased the horizontal regions. Charge transfer resistances decreased while double layer capacitance increased with acid concentration (Table 3).

Table 1. Parameters Derived from Anodic Polarization Curves in Various Concentration of $\mathrm{H}_{2} \mathrm{SO}_{4} \mathrm{Solutions}$

\begin{tabular}{|c|c|c|c|c|c|c|c|}
\hline \multirow{2}{*}{$\begin{array}{c}\text { Concentration of } \mathrm{H}_{2} \mathrm{SO}_{4} \text { (Normal- } \\
\text { ity) }\end{array}$} & \multirow{2}{*}{$\begin{array}{c}\text { OCP } \\
\text { mV } \\
v s \\
\text { SCE }\end{array}$} & \multicolumn{2}{|c|}{ Critical Range } & \multicolumn{2}{|c|}{ Primary Passivation Range } & \multicolumn{2}{|c|}{ Secondary Passivation Range } \\
\hline & & $\begin{array}{l}\text { Potential mV } \\
\text { vs SCE }\end{array}$ & $\begin{array}{c}\text { Current } \\
10^{-4} \mathrm{~A} / \mathrm{cm}^{2}\end{array}$ & $\begin{array}{l}\text { Potential mV } \\
\quad \text { vs SCE }\end{array}$ & $\begin{array}{c}\text { Current } \\
10^{-6} \mathrm{~A} / \mathrm{cm}^{2}\end{array}$ & $\begin{array}{l}\text { Potential mV } \\
\quad \text { vs SCE }\end{array}$ & $\begin{array}{l}\text { Current } \\
10^{-4} \mathbf{A} / \mathbf{c m}^{2}\end{array}$ \\
\hline 0.5 & -450 & -370 & 7 & -100 & 8.6 & 350 & 3.8 \\
\hline 1.0 & -420 & -370 & 8.5 & -80 & 9.2 & 350 & 5.1 \\
\hline 2.0 & -400 & -350 & 9.2 & -60 & 12 & 350 & 7.5 \\
\hline 5.0 & -380 & -350 & 12 & -50 & 40 & 350 & 9.0 \\
\hline
\end{tabular}






Fig. (3). Bode plots obtained for stainless steel in various concentrations of $\mathrm{H}_{2} \mathrm{SO}_{4}$ at active potential region $(-400 \mathrm{mV})$.

Table 3. Parameters Derived from Impedance Diagrams for Various Concentrations of $\mathrm{H}_{2} \mathrm{SO}_{4}$ at $\mathbf{- 4 0 0} \mathbf{~ m V}$ (Active Dissolution Range)

\begin{tabular}{|c|c|c|}
\hline $\begin{array}{c}\text { Concentration } \\
\text { of } \mathrm{H}_{2} \mathrm{SO}_{4} \\
\text { (Normality) }\end{array}$ & $\begin{array}{c}\text { Charge Transfer } \\
\text { Resistance } \\
\text { k. ohm/cm }\end{array}$ & $\begin{array}{c}\text { Double Layer } \\
\text { Capacitance } \\
\text { F/cm } \mathbf{c m}^{2} \times 10^{-3}\end{array}$ \\
\hline 0.5 & 291 & 3.6 \\
\hline 1.0 & 102 & 3.9 \\
\hline 2.0 & 55 & 6.2 \\
\hline 5.0 & 7 & 7.0 \\
\hline
\end{tabular}

\subsection{Primary Passivation Region}

When the log impedance was plotted against log frequency (Bode plots) in the primary passivation region at $100 \mathrm{mV}$, the vertical region increased with $\mathrm{H}_{2} \mathrm{SO}_{4}$ concentration (Fig. 4) Solution resistance decreased with $\mathrm{H}_{2} \mathrm{SO}_{4}$ concentration. The lower primary passivation charge transfer resistance values are due to the less stable newly formed thin film. Capacitance of the double layer increased with acid concentration (Table 4).

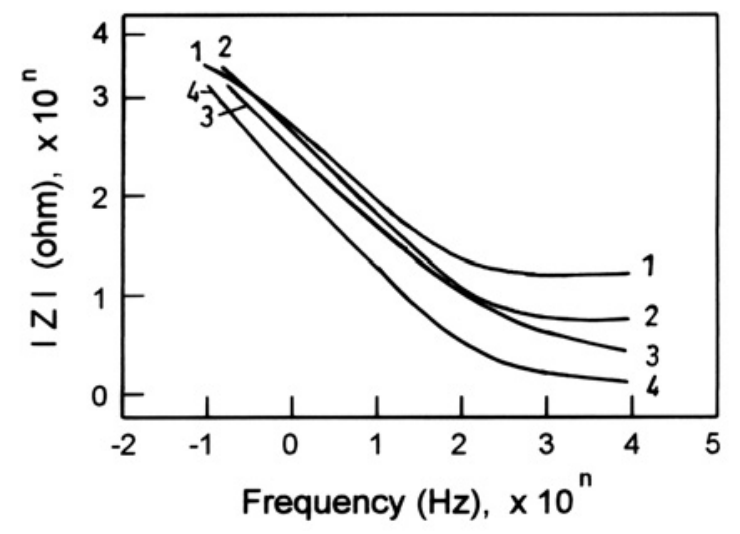

Fig. (4). Bode plots obtained for stainless steel in various concentrations of $\mathrm{H}_{2} \mathrm{SO}_{4}$ at the primary passivation region. (-100mV).
Table 4. Parameters Derived from Impedance Diagrams for Various Concentrations of $\mathrm{H}_{2} \mathrm{SO}_{4}$ at $\mathbf{- 1 0 0} \mathbf{~ m V}$ (Primary Passivation Range)

\begin{tabular}{|c|c|c|}
\hline $\begin{array}{c}\text { Concentration } \\
\text { of } \mathrm{H}_{2} \mathrm{SO}_{4} \\
\text { (Normality) }\end{array}$ & $\begin{array}{c}\text { Charge Transfer } \\
\text { Resistance } \\
\text { k. ohm/ } \mathbf{c m}^{2}\end{array}$ & $\begin{array}{c}\text { Double Layer } \\
\text { Capacitance } \\
\mathrm{F}^{-\mathbf{c m}^{2}} \times \mathbf{1 0}^{-4}\end{array}$ \\
\hline 0.5 & 3.4 & 4.50 \\
\hline 1.0 & 3.2 & 5.60 \\
\hline 2.0 & 2.1 & 7.54 \\
\hline 5.0 & 1.3 & 7.50 \\
\hline
\end{tabular}

The XPS pattern obtained on the protection film formed in $0.5 \mathrm{~N} \mathrm{H}_{2} \mathrm{SO}_{4}$ at $-100 \mathrm{mV}$ is shown as Fig. (5). The binding energies of all elements and their compounds are referred to using standard tables published by VG-XPS instrumentation Co., Ltd., The peaks at $574.0 \mathrm{eV}$ and $586.03 \mathrm{eV}$ are due to the presence of $2 p_{3 / 2}$ and $2 p^{1 / 2}$ electrons of chromium atom in $\mathrm{Cr}^{\mathrm{o}}$ state. Peaks at $576.4 \mathrm{eV}$ and $586.38 \mathrm{eV}$ are due to the presence of $2 p_{3 / 2}$ and $2 p^{1 / 2}$ electrons of chromium atom in $\mathrm{Cr}(\mathrm{OH})_{3}$. Peaks at $577.6 \mathrm{eV}, 578.6 \mathrm{eV}$ and $588.0 \mathrm{eV}, 586.03$

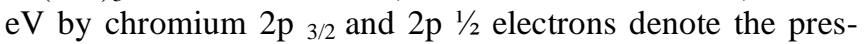
ence of chromium as $\mathrm{Cr}_{2} \mathrm{O}_{3}$. The peak at $579.0 \mathrm{eV}$ is due to the presence of $2 p_{3 / 2}$ electrons of chromium atoms in $\mathrm{CrOOH}$. The peak at $580.1 \mathrm{eV}$ noticed by $2 \mathrm{p}_{3 / 2}$ electrons of chromium is due to $\mathrm{CrO}_{3}$. The same binding energy for $\mathrm{Cr}$ $2 p_{3 / 2}$ was observed earlier [11-16]. The peak at $719.92 \mathrm{eV}$ is due to the presence of iron $2 p_{3 / 2}$ electron which indicates the free iron. Iron peaks observed at the binding energies of $707.0 \mathrm{eV}$ and $708.7 \mathrm{eV}$ are due to the presence of its $2 \mathrm{p}_{3 / 2}$ and $2 \mathrm{p}^{1 / 2}$ electrons which represent $\mathrm{Fe}^{2+}$ and $\mathrm{Fe}^{3+}$ states as oxide. The peaks at $706.82 \mathrm{eV}$ and $723.98 \mathrm{eV}$ indicate $2 \mathrm{p}_{3 / 2}$ and $2 \mathrm{p}^{1 / 2}$ electron of iron as $\mathrm{Fe}_{3} \mathrm{O}_{4}$ and $\mathrm{Fe}(\mathrm{OH})_{3}$. The peaks at $274.30 \mathrm{eV}$ and $725.27 \mathrm{eV}$ indicate iron in $2 \mathrm{p}_{3 / 2}$ state and thus $\alpha-\mathrm{Fe}_{2} \mathrm{O}_{3}$. The peaks at $710.9 \mathrm{eV}$ and $711.60 \mathrm{eV}$ by $\mathrm{Fe} 2 \mathrm{p}^{1 / 2}$ electron indicate $\gamma-\mathrm{FeOOH}$. The peaks at $724.97 \mathrm{eV}$ and $711.44 \mathrm{eV}$ are due to $\mathrm{Fe} 2 \mathrm{p}_{3 / 2}$ and $\mathrm{Fe} 2 \mathrm{p} 1 / 2$ electron level. These peaks denote the presence of $\alpha-\mathrm{FeOOH}$. The binding energies for iron and iron compounds observed in the present study are in conformity with earlier work. The peak observed at $638.76 \mathrm{eV}$ indicates $\mathrm{Mn}$ in $2 \mathrm{p}_{3 / 2}$ state. The peaks at 641.12 $\mathrm{eV}$ and $640.64 \mathrm{eV}$ suggest $\mathrm{Mn} 2 \mathrm{p}^{1 / 2}$ electrons in $\mathrm{Mn}_{2} \mathrm{O}_{3}$ and $\mathrm{Mn}^{4+}$ species. The peaks at $642.2 \mathrm{eV}, 641.0 \mathrm{eV}$ and $640.1 \mathrm{eV}$ suggest $\mathrm{Mn} 2 \mathrm{p}_{3 / 2}$ electrons. These indicate manganese as $\mathrm{Mn}_{2} \mathrm{O}_{3}, \mathrm{Mn}_{3} \mathrm{O}_{4}$ and $\mathrm{MnS}$ respectively. $\mathrm{MnS}$ existence is inferred from peak at $640.3 \mathrm{eV}$. The observed binding energies at $852.8 \mathrm{eV}, 854.0 \mathrm{eV}, 856.5 \mathrm{eV}, 854.1 \mathrm{eV}, 856.9 \mathrm{eV}$ and $854.9 \mathrm{eV}$ suggest $\mathrm{Ni} 2 \mathrm{p}_{3 / 2}$ electrons and nickel existence as $\mathrm{Ni}, \mathrm{NiO}, \mathrm{Ni}(\mathrm{OH})_{2}, \mathrm{Ni}_{2} \mathrm{O}_{3}$ and $\mathrm{NiO}$ respectively. The binding energies for nickel and its oxides has been observed earlier confirm this [17-22]. The peaks obtained at $530.1 \mathrm{eV}, 531.5$ $\mathrm{eV}, 533.0 \mathrm{eV}$ suggest oxygen in $1 \mathrm{~s}^{1} / 2$ state and suggest oxygen to be present as $\mathrm{O}^{2-}, \mathrm{OH}^{-}$and $\mathrm{H}_{2} \mathrm{O}-\mathrm{SO}_{4}{ }^{2-}$ respectively. The binding energies correspond to $162.4 \mathrm{eV}$ and $169.0 \mathrm{eV}$

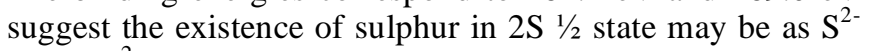
and $\mathrm{SO}_{4}{ }^{2-}$ respectively.

Fig. (8) presents the XPS patterns of the film formed from $5.0 \mathrm{~N} \mathrm{H}_{2} \mathrm{SO}_{4}$ solutions at $-50 \mathrm{mV}$. The appearance of a peak at $574.0 \mathrm{eV}$ indicates $\mathrm{Cr}^{\mathrm{o}}$ and $\mathrm{Cr} 2 \mathrm{p}_{3 / 2}$ states. The peaks 

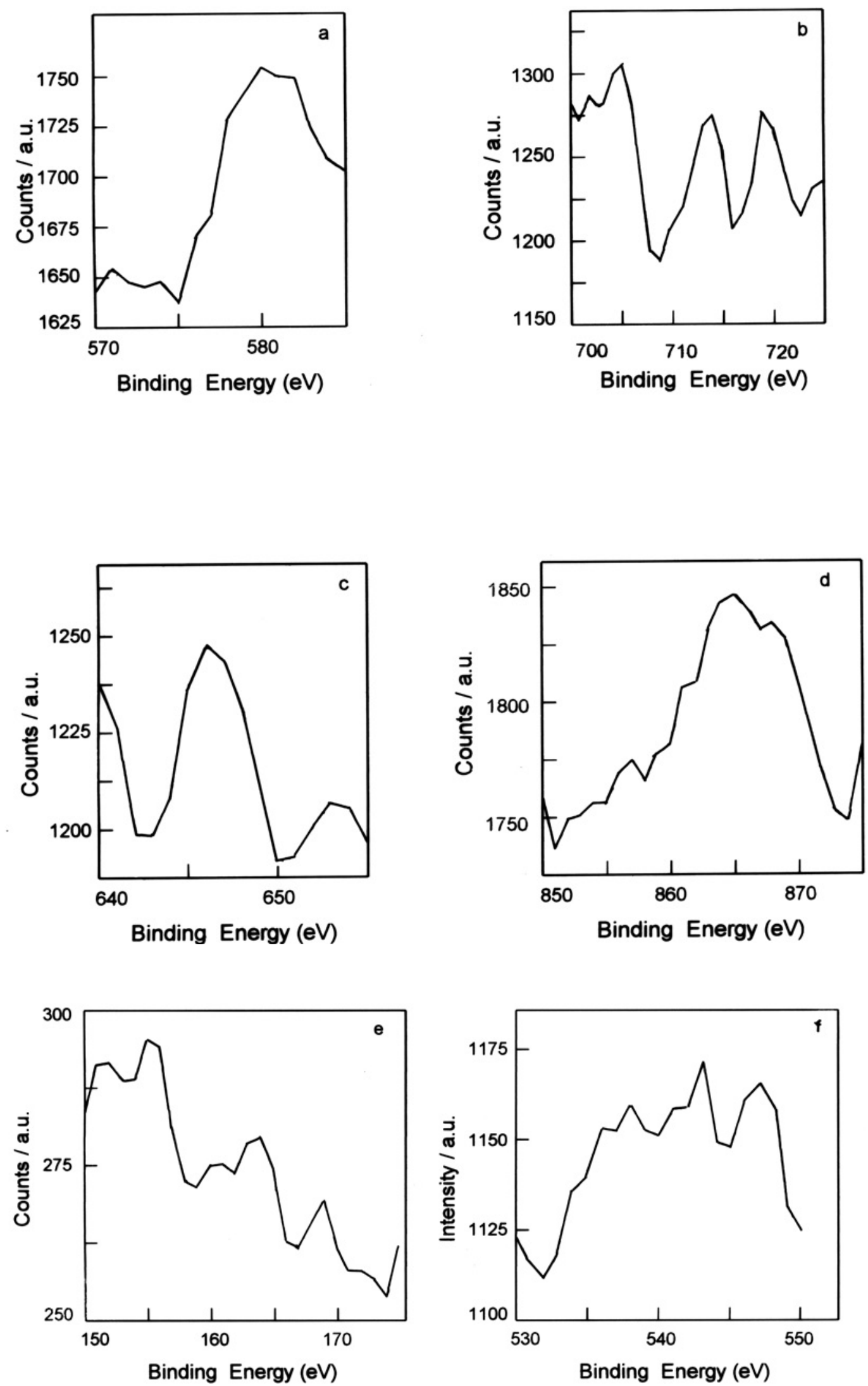

Fig. (5). XPS pattern obtained from primary passive layer of stainless steel in $0.5 \mathrm{~N} \mathrm{H}_{2} \mathrm{SO}_{4}$. (at $-100 \mathrm{mV}$ ). (a) chromium, (b) iron, (c) manganese, (d) nickel, (e) sulphur and (f). oxygen. 
observed at $576.4 \mathrm{eV}$ and $578.6 \mathrm{eV}$ indicate $\mathrm{Cr} 2 \mathrm{p}_{3 / 2}$ electrons and $\mathrm{Cr}_{2} \mathrm{O}_{3}$ presence in the film. The peaks at $577.6 \mathrm{eV}$ and 586.38 suggest $\mathrm{Cr} 2 \mathrm{p}_{3 / 2}$ and $\mathrm{Cr} 2 \mathrm{p}_{1 / 2}$ core electrons. These peaks denote the presence of $\mathrm{Cr}(\mathrm{OH})_{3}, \mathrm{Cr} 2 \mathrm{p}_{3 / 2}$ core electron as indicated by the peak at $579.0 \mathrm{eV}$ suggesting the presence of $\mathrm{CrOOH}$. The existence of $\mathrm{CrO}_{3}$ was inferred from a peak at $580.1 \mathrm{eV}$.

The $\mathrm{Fe} 2 \mathrm{p}_{3 / 2}$ electron gave the peaks at $706.82 \mathrm{eV}, 710.97$ $\mathrm{eV}, 711.60 \mathrm{eV}$ and $711.44 \mathrm{eV}$. These peaks indicate the presence of $\mathrm{Fe}_{3} \mathrm{O}_{4}, \alpha \mathrm{Fe}_{2} \mathrm{O}_{3}, \gamma-\mathrm{FeOOH}$ and $\alpha-\mathrm{FeOOH}$ respectively. The existence of $\mathrm{Fe}_{3} \mathrm{O}_{4}, \mathrm{Fe}, \alpha-\mathrm{Fe}_{2} \mathrm{O}_{3}, \gamma-\mathrm{FeOOH}$ and $\alpha-\mathrm{FeOOH}$ is inferred from $\mathrm{Fe} 2 \mathrm{p}_{3 / 2}$ electrons at $723.98 \mathrm{eV}$, $719.92 \mathrm{eV}, 724.30 \mathrm{eV}, 725.2 \mathrm{eV}$ and $724.97 \mathrm{eV}$.

The peaks observed at $638.76 . \mathrm{eV}, 641.12 \mathrm{eV}$ and 642.2 $\mathrm{eV}$ are due to $\mathrm{Mn} 2 \mathrm{p}_{3 / 2}$ electrons. These indicate the existence of $\mathrm{Mn}^{\mathrm{o}}, \mathrm{Mn}(\mathrm{OH})_{3}, \mathrm{Mn}_{2} \mathrm{O}_{3}$ and $\mathrm{MnO}_{2}$. The peaks appeared at $852.8 \mathrm{eV}, 854.0 \mathrm{eV}, 856.5 \mathrm{eV}, 854.9 \mathrm{eV}, 856.9 \mathrm{eV}$ and $854.9 \mathrm{eV}$ are due to $\mathrm{Ni} 2 \mathrm{p}_{3 / 2}$ electrons suggesting $\mathrm{Ni}, \mathrm{NO}$, $\mathrm{Ni}(\mathrm{OH})_{2}, \mathrm{NiS}, \mathrm{Ni}_{2} \mathrm{O}_{3}$ and $\mathrm{NiO}$ respectively. The existence of $\mathrm{S}^{2-}$ and $\mathrm{SO}_{4}{ }^{2-}$ species are inferred from the peaks at $162.4 \mathrm{eV}$ and $169.4 \mathrm{eV}$. The oxygen species $\mathrm{O}^{2-}, \mathrm{OH}^{-}, \mathrm{H}_{2} \mathrm{O}-\mathrm{SO}_{4}{ }^{2-}$ are inferred from the peaks at $530.2 \mathrm{eV}, 531.4 \mathrm{eV}$ and $532.9 \mathrm{eV}$. The peaks at $530.17 \mathrm{eV}, 529.98 \mathrm{eV}, 530.2 \mathrm{eV}, 530.3 \mathrm{eV}$, $529.98 \mathrm{eV}, 530.85 \mathrm{eV}$ and $530.01 \mathrm{eV}$ suggest $\mathrm{O} 1 \mathrm{~s} 1 / 2$ electron and $\mathrm{O}-\mathrm{M}$ bonds, $\mathrm{Fe}_{3} \mathrm{O}_{4}, \alpha-\mathrm{Fe}_{2} \mathrm{O}_{3}, \gamma-\mathrm{FeOOH}, \alpha-\mathrm{FeOOH}$, $\mathrm{Cr}_{2} \mathrm{O}_{3}, \mathrm{Cr}(\mathrm{OH})_{3} .0 .4 \mathrm{H}_{2} \mathrm{O}$ and $\mathrm{CrO}_{3}$ respectively. The peak at $531.4 \mathrm{eV}$ is due to $\mathrm{O} 1 \mathrm{~S} 1 / 2$ electron in $\gamma-\mathrm{FeOOH}$ and $\alpha$ $\mathrm{FeOOH}$.

\subsection{Secondary Passivation Range}

Fig. (6) presents the Bode plots in different concentrations obtained at $350 \mathrm{mV}$ (secondary passivation range). The horizontal region at higher frequency is not sharp. There is not much variation in the slopes of the vertical portions. The charge transfer resistances are higher compared to those obtained in primary passivation range and $\mathrm{C}_{\mathrm{dl}}$ values are lower (Table 5).

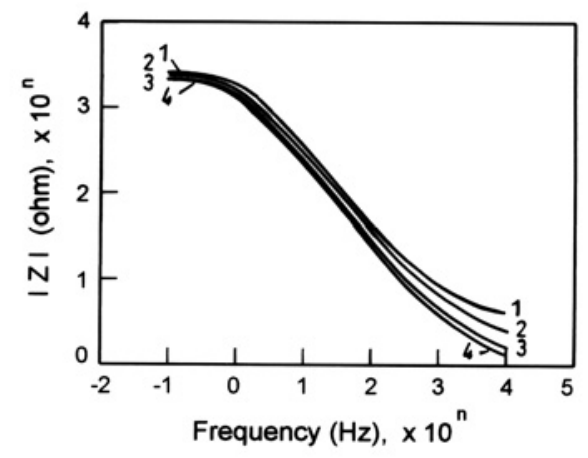

Fig. (6). Bode plots for stainless steel in various concentrations of $\mathrm{H}_{2} \mathrm{SO}_{4}$ obtained at secondarypassive potential region. (350mV).

Fig. (7) presents XPS patterns observed on the surface kept at $350 \mathrm{mV}$ in $0.5 \mathrm{H} \mathrm{H}_{2} \mathrm{SO}_{4}$. The observed peaks at $578.6 \mathrm{eV}$ and $579.0 \mathrm{eV}$ suggest the presence of chromium as $2 \mathrm{p}_{3 / 2}$ electrons and $\mathrm{Cr}_{2} \mathrm{O}_{3}$ or $\mathrm{CrOOH}$ on the surface film. The peaks at $586.03 \mathrm{eV}, 586.38 \mathrm{eV}$ and $588.0 \mathrm{eV}$ suggest the presence of chromium as $\mathrm{Cr}_{2} \mathrm{O}_{3}, \mathrm{Cr}(\mathrm{OH})_{3}$ and $\mathrm{CrO}_{3}$ respectively.
The presence of $\mathrm{FeO}$ and $\mathrm{Fe}^{3+}$ state with film was inferred from the peaks obtained at $708.7 \mathrm{eV}$ and $707.0 \mathrm{eV}$ respectively. The peaks at $710.6 \mathrm{eV}$ corresponding to $\mathrm{Fe} 2 \mathrm{p}_{3 / 2}$ indicate the presence of $\mathrm{Fe}(\mathrm{OH})_{3} . \mathrm{Fe}_{3} \mathrm{O}_{4}$ presence is indicated by $706.82 \mathrm{eV}\left(\mathrm{Fe} 2 \mathrm{p}_{3 / 2}\right)$ and $723.9 \mathrm{eV}\left(\mathrm{Fe} 2 \mathrm{p}_{1 / 2}\right)$. The peaks at $724.30 \mathrm{eV}$ and $725.27 \mathrm{eV}$ indicate $\alpha-\mathrm{Fe}_{2} \mathrm{O}_{3}$ in the film. The peak at $710.9 \mathrm{eV}$ given by $\mathrm{Fe} 2 \mathrm{p}_{1 / 2}$ core electron denotes the presence of $\gamma-\mathrm{FeOOH}$. The presence of $\alpha-\mathrm{FeOOH}$ is indicated by the peaks at $724.97 \mathrm{eV}$ and at $711.44 \mathrm{eV}\left(\mathrm{Fe} 2 \mathrm{p}_{3 / 2}\right.$ and $\mathrm{Fe} 2 \mathrm{p}_{1 / 2}$ core electrons). The peaks obtained at $638.76 \mathrm{eV}$, $641.12 \mathrm{eV}, 640.64 \mathrm{eV}$ and $642.2 \mathrm{eV}$ are due to $\mathrm{Mn} 2 \mathrm{p}_{3 / 2}$ electrons. The film may contain $\mathrm{Mn}^{\mathrm{o}}, \mathrm{Mn}^{3+}$, and $\mathrm{Mn}^{+}$species. The existence of $\mathrm{Mn}_{2} \mathrm{O}_{3}, \mathrm{Mn}_{3} \mathrm{O}_{4}$ and $\mathrm{MnS}$ are inferred by $\mathrm{Mn} 2 \mathrm{p}_{\frac{1}{2}}$ electrons as revealed by the peaks at $642.2 \mathrm{eV}$, $641.0 \mathrm{eV}$ and $640.3 \mathrm{eV}$. Nickel may be present as $\mathrm{Ni}^{\circ}, \mathrm{Ni}^{2+}$ in $\mathrm{NiO}$ and $\mathrm{Ni}(\mathrm{OH})_{2}$ as suggested by the peaks at $852.8 \mathrm{eV}$, 854.0eV, 856.5eV, 854.1eV, 856.9eV and 854.9eV. Sulphur may be present in the film as $\mathrm{S}^{2-}$ as revealed by the observed peak at $162.4 \mathrm{eV}$.

Table 5. Parameters Derived from Impedance Diagrams for Various Concentrations of $\mathrm{H}_{2} \mathrm{SO}_{4}$ at $+300 \mathrm{mV}$ (Secondary Passivation Range)

\begin{tabular}{|c|c|c|}
\hline $\begin{array}{c}\text { Concentration } \\
\text { of } \mathbf{H}_{2} \mathbf{S O}_{4} \\
\text { (Normality) }\end{array}$ & $\begin{array}{c}\text { Charge Transfer } \\
\text { Resistance } \\
\text { k. ohm/.cm }\end{array}$ & $\begin{array}{c}\text { Double Layer } \\
\text { Capacitance } \\
\text { F/cm }^{2} \mathbf{~} \mathbf{~ 1 0}^{-4}\end{array}$ \\
\hline \hline 0.5 & 13.6 & 1.20 \\
\hline 1.0 & 13.2 & 1.25 \\
\hline 2.0 & 13.0 & 1.70 \\
\hline 5.0 & 9.4 & 2.30 \\
\hline
\end{tabular}

Fig. (9) presents the XPS spectra obtained in the secondary passivation range $($ at $350 \mathrm{mV})$ in $5.0 \mathrm{~N}_{2} \mathrm{SO}_{4}$. The peaks at $576.03 \mathrm{eV}, 586.38 \mathrm{eV}, 588.3 \mathrm{e}$ are due to $\mathrm{Cr} 2 \mathrm{p}_{3 / 2}$ and the peaks at $586.0-3 \mathrm{eV}, 586.38 \mathrm{eV}$ and $588.32 \mathrm{eV}$ are due to $\mathrm{Cr} 2 \mathrm{p}_{1 / 2}$. These suggest the presence of $\mathrm{Cr}_{2} \mathrm{O}_{3}, \mathrm{Cr}(\mathrm{OH})_{3} .0 .4$ $\mathrm{H}_{2} \mathrm{O}, \mathrm{CrO}_{3}$ respectively. $\mathrm{Cr} 2 \mathrm{p}_{3 / 2}$ electron gives rise to peaks at $579.8 \mathrm{eV}$ and suggests $\mathrm{CrOOH}$ in the film. The peaks at $710.95 \mathrm{eV}, 710.97 \mathrm{eV}$ and $711.60 \mathrm{eV}$ suggest $\mathrm{Fe} 2 \mathrm{p}_{3 / 2}$ electrons and $\mathrm{Fe}_{3} \mathrm{O}_{4}, \alpha-\mathrm{Fe}_{2} \mathrm{O}_{3}, \gamma-\mathrm{FeOOH}$ presence in the film. $\mathrm{Fe} 2 \mathrm{P} 1 / 2$ electrons gave rise to the peaks at $723.98 \mathrm{eV}, 724.30 \mathrm{eV}$ and suggest the incorporation of $\mathrm{Fe}_{3} \mathrm{O}_{4}$ and $\alpha \mathrm{Fe}_{2} \mathrm{O}_{3}$ in the film. The peaks at $642.2 \mathrm{eV}, 641.8 \mathrm{eV}$ suggest $\mathrm{Mn} 2 \mathrm{p}^{1 / 2}$ electrons and $\mathrm{MnO}_{2}$ and $\mathrm{MnS}$ in the film. The peaks at $852.8 \mathrm{eV}$, $854.0 \mathrm{eV}, 856.5 \mathrm{eV}, 854.1 \mathrm{eV}, 856.9 \mathrm{eV}$ and $854.9 \mathrm{eV}$ suggest $\mathrm{Ni} 2 \mathrm{p}_{3 / 2}$ electrons and the presence of $\mathrm{Ni}^{\mathrm{o}}, \mathrm{NiO}, \mathrm{Ni}(\mathrm{OH})_{2}$, $\mathrm{NiS}, \mathrm{Ni}_{2} \mathrm{O}_{3}, \mathrm{NiO}$ respectively. The peaks at $529.98 \mathrm{eV}$, $531.4 \mathrm{eV}$ and $533.0 \mathrm{eV}$ suggest $\mathrm{O} 1 \mathrm{~s} 1 / 2$ electron and the presence of $\mathrm{M}-\mathrm{O}, \mathrm{OH}^{-}, \mathrm{H}_{2} \mathrm{O}-\mathrm{SO}_{4}{ }^{2-}$ in the film respectively. The presence of $\mathrm{S}^{2-}$ and $\mathrm{SO}_{4}{ }^{2-}$ in the film was inferred from the $\mathrm{S} 2 \mathrm{P}^{1} / 2$ peaks at $162.4 \mathrm{eV}$ and $169.0 \mathrm{eV}$.

\subsection{Transpassive Region}

Fig. (10) presents the Bode plot obtained in the transpassive region at $600 \mathrm{mV}$. The charge transfer resistances decreased while the double layer capacitances increased. Enhanced double layer capacitance is due to the adsorption of oxygen atom on the surface of the film (Table 6). 

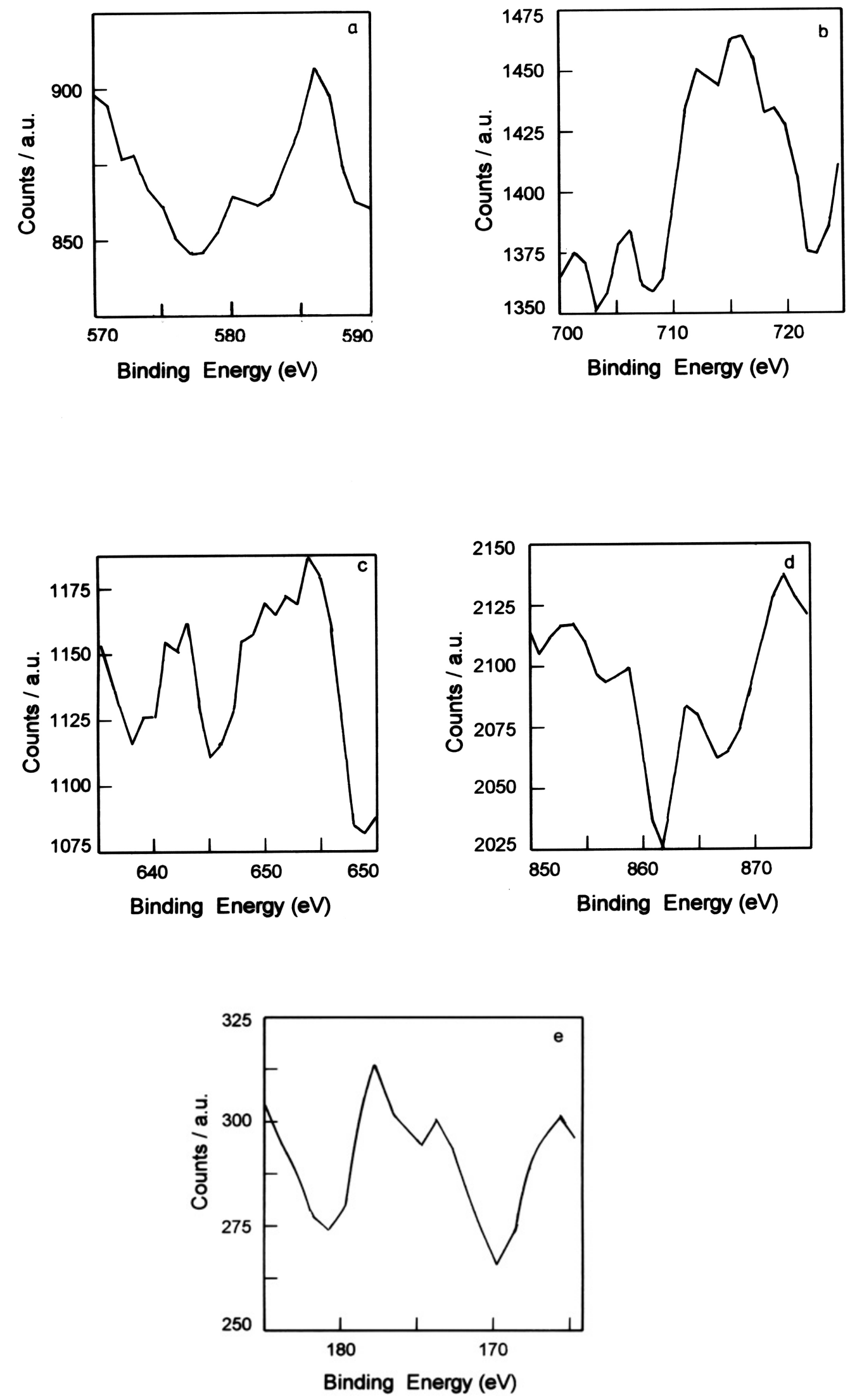

Fig. (7). XPS pattern obtained from secondary passive layer of stainless steel in $0.5 \mathrm{~N} \mathrm{H}_{2} \mathrm{SO}_{4}$. (at $350 \mathrm{mV}$ ). (a) chromium, (b) iron, (c) manganese, (d) nickel, and (e) oxygen. 

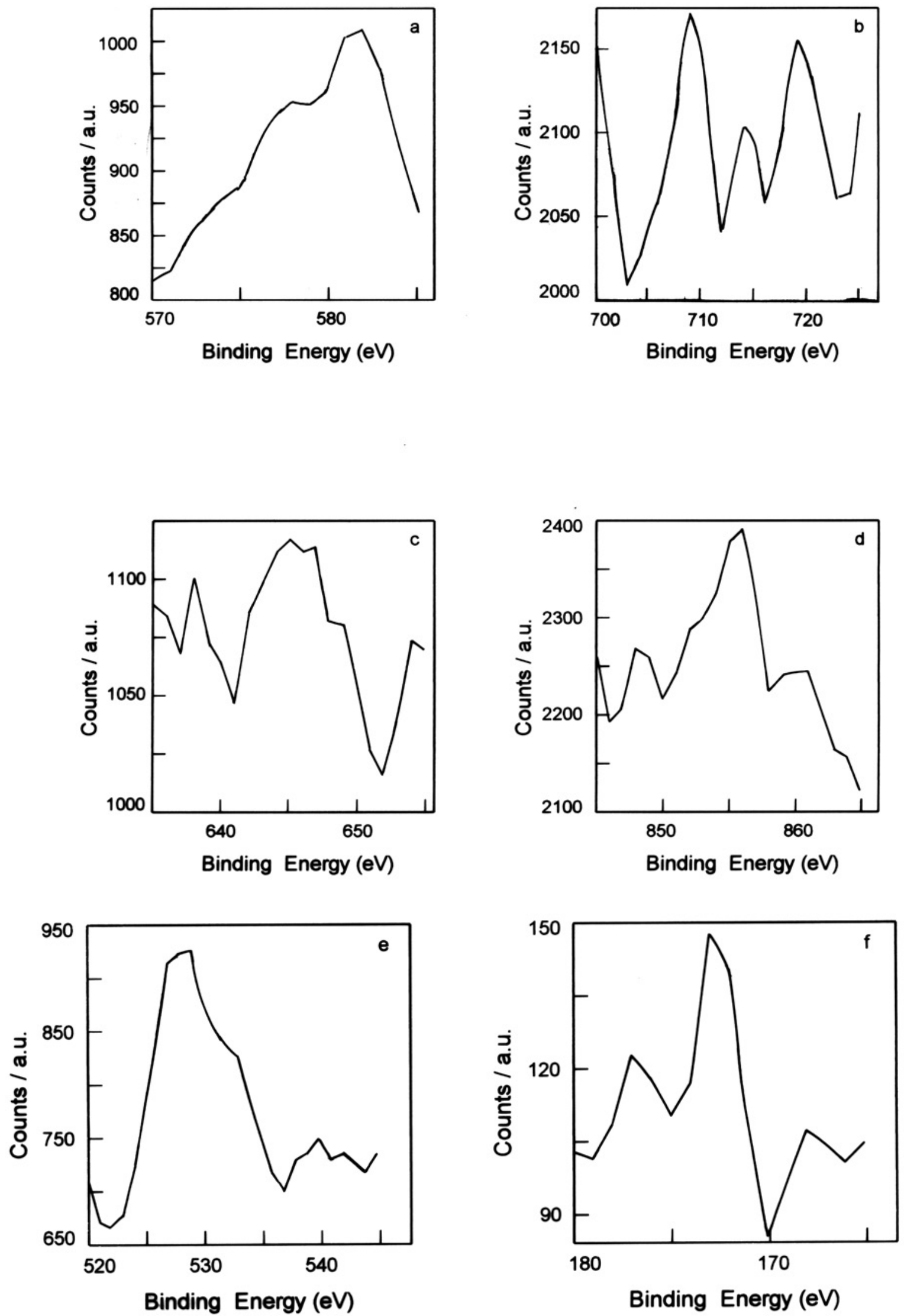

Fig. (8). XPS pattern obtained from primary passive layer of stainless steel in $5.0 \mathrm{~N} \mathrm{H}_{2} \mathrm{SO}_{4}(-50 \mathrm{mV})$. (a) chromium, (b) iron, (c) manganese, (d) nickel, (e) oxygen and (f) sulphur. 

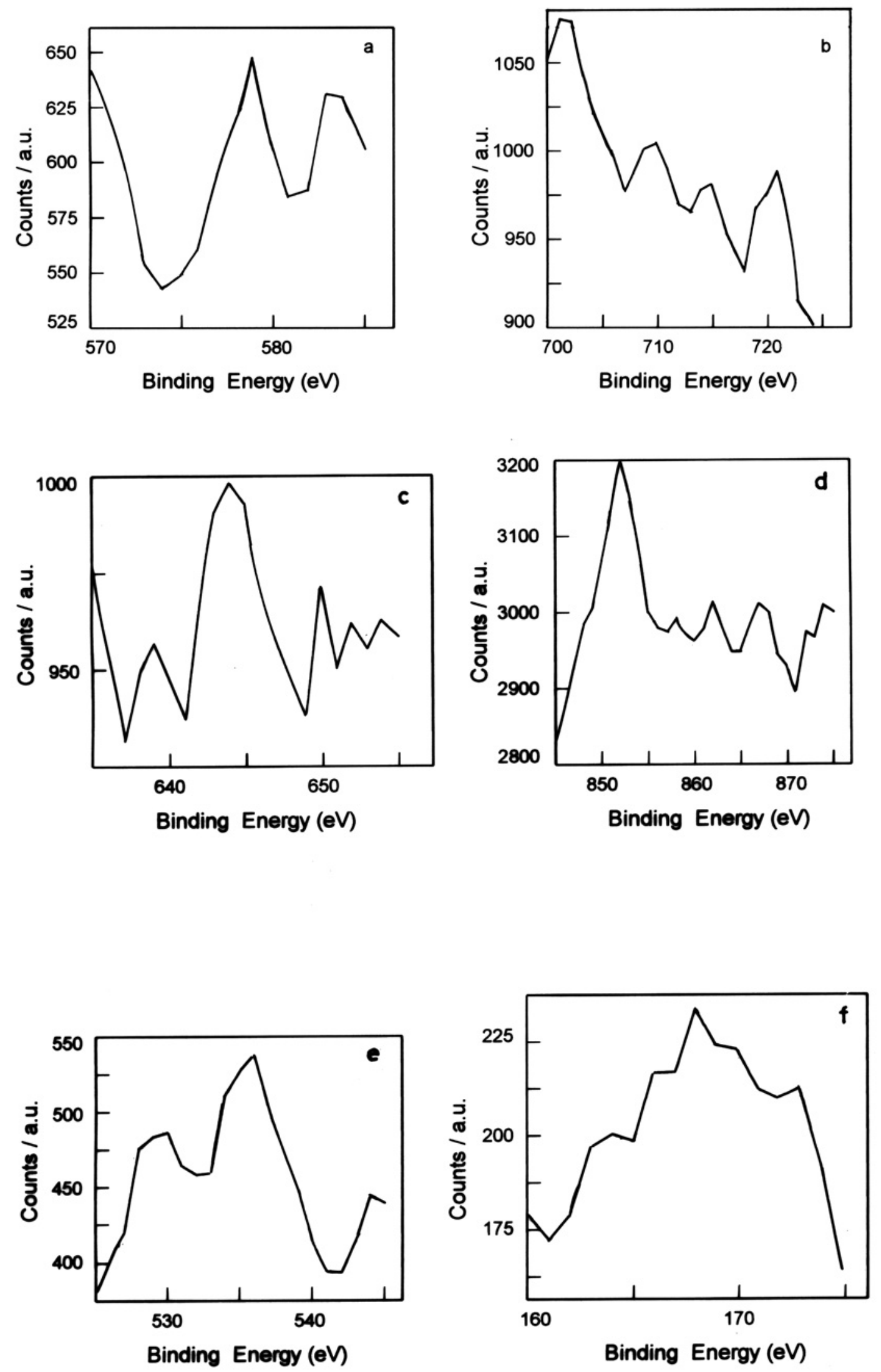

Fig. (9). XPS pattern obtained from secondary passive layer of stainless steel in $5.0 \mathrm{~N}_{2} \mathrm{SO}_{4}(350 \mathrm{mV})$. (a) chromium, (b) iron, (c) manganese, (d) nickel, (e) oxygen and (f) sulphur. 


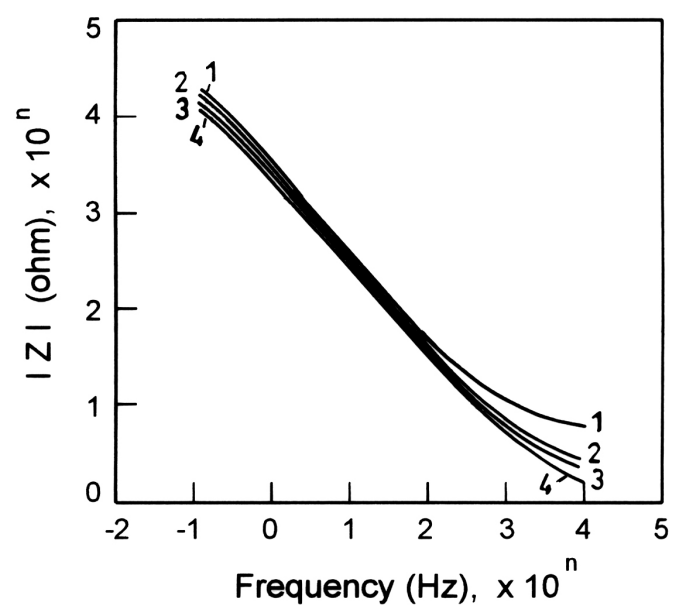

Fig. (10). Bode plots for stainless steel in various concentrations of $\mathrm{H}_{2} \mathrm{SO}_{4}$ obtained at trans-passive potential region. $(450 \mathrm{mV})$.

\section{DISCUSSION}

Dissolution, passivation and depassivation on metals has been reviewed [23-25]. In general dissolution of metal occurs as

$$
\begin{aligned}
& \mathrm{M}+\mathrm{OH}^{-} \rightleftharpoons \mathrm{MOH}_{\mathrm{ads}}^{-}+\mathrm{e} \\
& \mathrm{MOH}_{\mathrm{ads}}^{-} \rightleftharpoons \mathrm{MOH}_{\mathrm{ads}}+\mathrm{e} \\
& \mathrm{MOH}_{\mathrm{ads}} \rightarrow \mathrm{M}^{2+}+\mathrm{OH}^{-}
\end{aligned}
$$

The adsorbed intermediates cover the surface $\left(\theta_{\mathrm{MOH}}\right)$. The film formation may occur directly or indirectly. In indirect film formation, the film nucleation occurs in the solution while in the direct film formation it takes place on the surface. The dissolution precipitation mechanism is covered by metal dissolution, prepassivating film formation and film growth at higher potentials.

In the present study the observed peaks at $530.1 \mathrm{eV}$, $531.5 \mathrm{eV}$ and $533.0 \mathrm{eV}$ suggest the presence of oxygen as $\mathrm{O}^{2-}$ and $\mathrm{OH}^{-}$ions. Water is bound inside the film. The desorption and dehydration of water molecules favour the film growth. The film may contain $\mathrm{M}-\mathrm{H}_{2} \mathrm{O}$ bonds as $\mathrm{H}_{2} \mathrm{O}-\mathrm{M}-\mathrm{H}_{2} \mathrm{O}$, HO-M$\mathrm{OH}$ or O-M-O. Depending upon the anodic potential, film grows. The film on stainless steel was found earlier to be polycrystalline [26]. Sulphate ions adsorb on the surface and favour $\mathrm{H}_{2} \mathrm{O}-\mathrm{SO}_{4}{ }^{2-}$ bonds. On $\mathrm{Fe}-\mathrm{Cr}(13 \%)$ alloy, the passive film was found to contain hydrated chromium hydroxide on the inner chromium rich inner layer, $\mathrm{OH}^{-}$ions and adsorb water molecules on this inner layer. In $\mathrm{H}_{2} \mathrm{SO}_{4} / \mathrm{Na}_{2} \mathrm{SO}_{4}$ solutions, the film contained iron oxide, hydroxide and chromium $[27,28]$. In the present study in the primary passivation range $\mathrm{Cr}_{2} \mathrm{O}_{3}, \mathrm{CrOOH}$ species were identified.

Table 7 summarizes species identified in the primary and secondary passive region on the film. XPS studies revealed an enrichment of chromium the passive film in the primary range in $0.5 \mathrm{~N} \mathrm{H}_{2} \mathrm{SO}_{4}$ while increase of acid concentration favoured iron enrichment in the secondary passive range. Oxides enrichment was higher in dilute acid. Film formation required less coulombs of electricity in dilute acid. Higher acid concentration favoured dissolution. Qualitatively oxides of chromium, iron and nickel were found to be more in the primary passivation range than in the secondary passivation range.

Table 6. Parameters Derived from Impedance Diagrams for Various Concentrations of $\mathrm{H}_{2} \mathrm{SO}_{4}$ at $600 \mathrm{mV}$ (Transpassive Region)

\begin{tabular}{|c|c|c|}
\hline $\begin{array}{c}\text { Concentration } \\
\text { of } \mathbf{H}_{2} \mathbf{S O}_{4} \\
\text { (Normality) }\end{array}$ & $\begin{array}{c}\text { Charge Transfer } \\
\text { Resistance } \\
\mathbf{k . ~ o h m} / \mathbf{c m}^{2}\end{array}$ & $\begin{array}{c}\text { Double Layer } \\
\text { Capacitance } \\
\mathbf{F}^{2} \mathbf{c m}^{2} \mathbf{~ \mathbf { ~ 1 0 } ^ { - 5 }}\end{array}$ \\
\hline \hline 0.5 & 22.6 & 7.2 \\
\hline 1.0 & 18.3 & 8.2 \\
\hline 2.0 & 16.1 & 9.5 \\
\hline 5.0 & 13.6 & 12.0 \\
\hline
\end{tabular}

Table 7. Summary of the Compounds Likely to be Present in the Passive Film - XPS Study

\begin{tabular}{|c|c|}
\hline Primary Passivation Range & Secondary Passivation Range \\
\hline \hline $\mathrm{CrOOH}, \mathrm{Cr}_{2} \mathrm{O}_{3}, \mathrm{CrO}_{3}$ & $\mathrm{Cr}_{2} \mathrm{O}_{3}, \mathrm{Cr}(\mathrm{OH})_{3}, \mathrm{CrO}_{3}$ \\
$\gamma-\mathrm{Fe}_{2} \mathrm{O}_{3}, \gamma \mathrm{FeOOH}$ & $\mathrm{Fe}(\mathrm{OH})_{3}, \alpha-\mathrm{Fe}_{2} \mathrm{O}_{3}, \gamma \mathrm{FeOOH}$ \\
$\mathrm{Mn}_{2} \mathrm{O}_{3}, \mathrm{Mn}_{3} \mathrm{O}_{4}, \mathrm{MnS}$ & $\mathrm{Fe}_{3} \mathrm{O}_{4}, \alpha-\mathrm{FeOOH}$ \\
$\mathrm{Ni}(\mathrm{OH})_{2}, \mathrm{Ni}_{2} \mathrm{O}_{3}, \mathrm{NiO}$ & $\mathrm{Mn}_{2} \mathrm{O}_{3}, \mathrm{Mn}_{3} \mathrm{O}_{4}, \mathrm{MnS}, \mathrm{MnO}_{2}$ \\
$\mathrm{~S}^{-}, \mathrm{SO}_{4}{ }^{2-}$ & $\mathrm{NiO}, \mathrm{Ni}(\mathrm{OH})_{2}$ \\
& $\mathrm{~S}^{2-}, \mathrm{SO}_{4}{ }^{2-}$ \\
\hline
\end{tabular}

Dissolution of iron in $\mathrm{H}_{2} \mathrm{SO}_{4}$ was found to occur as [29],

$$
\begin{aligned}
& \mathrm{Fe}+\mathrm{H}_{2} \mathrm{O} \rightleftharpoons \mathrm{FeOH}+\mathrm{H}^{+}+\mathrm{e} \\
& \mathrm{FeOH} \rightarrow \mathrm{FeOH}^{+}+\mathrm{e} \\
& \mathrm{FeOH}^{+} \rightarrow \mathrm{Fe}^{2+}+\mathrm{OH}^{-}
\end{aligned}
$$

It is known that in $1 \mathrm{M}$ sulphate and $1 \mathrm{M}$ chloride solutions iron dissolved with the formation of $\mathrm{Fe}(\mathrm{OH})_{2}$ ads. [30].

In the present anodic polarization, iron dissolves through $\mathrm{Cr}_{2} \mathrm{O}_{3}$ film and reacted with $\mathrm{H}_{2} \mathrm{SO}_{4}$ to form $\mathrm{FeOH}, \mathrm{Fe}^{2+}$ species.

$\mathrm{Fe} \mathrm{OH}+\mathrm{OH}^{-} \rightarrow \mathrm{Fe}(\mathrm{OH})_{2}+\mathrm{e}$

The passive film formation may occur directly or indirectly. In indirect film formation the film nucleation occurs in solution (Classical dissolution precipitation model) while direct film formation theories assert that the film nucleation takes place directly at the solid surface.

$$
\mathrm{Fe}(\mathrm{OH})_{2}+\mathrm{OH}^{-} \rightarrow \mathrm{Fe}(\mathrm{OH})_{3}+\mathrm{e}^{-}
$$

which may undergo structural changes to $\alpha-\mathrm{Fe}_{2} \mathrm{O}_{3}$

$2 \mathrm{Fe}(\mathrm{OH})_{3} \rightarrow \alpha-\mathrm{Fe}_{2} \mathrm{O}_{3}+3 \mathrm{H}_{2} \mathrm{O}$

and further anodic polarization favours

$$
2 \mathrm{Fe}(\mathrm{OH})+\mathrm{Fe}(\mathrm{OH})_{2} \rightarrow \mathrm{Fe}_{3} \mathrm{O}_{4}+4 \mathrm{H}^{+}+4 \mathrm{e}
$$

The observed peaks at $706.82 \mathrm{eV}$ and $723.98 \mathrm{eV}$ confirm the presence of $\mathrm{Fe}(\mathrm{OH})_{3}$. The presence of $\alpha-\mathrm{Fe}_{2} \mathrm{O}_{3}$ was confirmed by the peaks at $724.30 \mathrm{eV}$ and $725.27 \mathrm{eV} . \alpha-\mathrm{FeOOH}$ presence was indicated by the peaks at $724.97 \mathrm{eV}$ and $711.44 \mathrm{eV}$. 
It was shown that a surface of stainless steel exposed to deaerated $1 \mathrm{M} \mathrm{H}_{2} \mathrm{SO}_{4}+0.5 \mathrm{M} \mathrm{HCl}$ solution [31] on anodic polarization, the surface was found to contain surface $\mathrm{Cr}$-rich oxide film responsible for maintaining passivity of stainless steel. This enrichment of $\mathrm{Cr}$ in the passive film of $\mathrm{Fe}-\mathrm{Cr}$ alloys and stainless steel was due to both the lower mobility of $\mathrm{Cr}$ in the film and the preferential dissolution of iron into the electrolyte. The Cr-rich film was suggested to consist of a hydrated form of $\mathrm{CrOOH}[32,33]$, while Olefjord claimed that $\mathrm{Cr}_{2} \mathrm{O}_{3}$ was the main passivating compound [34]. In the initial passivating process, it was suggested that $\mathrm{Cr}$ directly reacts with water to form $\mathrm{Cr}_{2} \mathrm{O}_{3}$, followed by the formation of $\mathrm{Cr}(\mathrm{OH})_{3}$ at the oxide-solution interface. The ironoxyhydroxide or iron hydroxide appears to be formed with $\mathrm{Cr}(\mathrm{OH})_{3}$, resulting in the formation of a duplex hydroxide layer [35]. On the chromium oxide, the dissolved iron formed oxide like $\alpha . \mathrm{Fe}_{2} \mathrm{O}_{3}$ and $\mathrm{Fe}_{3} \mathrm{O}_{4}$. Further polarization enriches the chromium content in the film. The nature of the semi conducting passive film changes on polarization [31]. Changes in double layer capacitances with acid concentration and anodic potentials suggest that the transition occurs from n-type to p-type conductivity [36]. Photo electrochemical studies in $0.05 \mathrm{M} \mathrm{H}_{2} \mathrm{SO}_{4}$ revealed that the protective property of the film depends on chromium content in the alloy [37-39].

In the present study chromium enrichment favoured protection and increase of acid concentration enhanced iron dissolution through the film (Table 1). At moderate anodic potentials, nickel and manganese dissolve to from their oxides. Sulphides incorporation in the film may also arise as the 304-SS alloy contains 0.026 weight \% of sulphur. Sulphates may also be reduced by the protons released during polarization (chemical reaction).

In the transpassive region, oxygen evolution may occur on an oxide surface as

$$
\begin{aligned}
& \mathrm{H}_{2} \mathrm{O} \rightleftharpoons \mathrm{OH}_{\mathrm{ads}}+\mathrm{H}^{+}+\mathrm{e} \\
& \mathrm{OH}^{-}+\mathrm{OH}_{\mathrm{ads}} \rightleftharpoons \mathrm{O}_{\mathrm{ads}}^{-}+\mathrm{H}_{2} \mathrm{O} \\
& \mathrm{O}_{\mathrm{ads}}^{-} \rightleftharpoons \mathrm{O}_{\mathrm{ads}}+\mathrm{e} \\
& 2 \mathrm{O}_{\mathrm{ads}} \rightleftharpoons \mathrm{O}_{2} \uparrow
\end{aligned}
$$

The oxygen evolution from an oxide film involves the participation of adsorbed oxygen atom. If the desorption of oxygen atom is slow, there would be accumulation of oxygen on the surface which changed the double layer capacitance (Table 5).

\section{CONCLUSION}

XPS studies carried out on 304 stainless steel in $\mathrm{H}_{2} \mathrm{SO}_{4}$ solutions revealed the existence of $\mathrm{CrOOH}, \mathrm{Cr}_{2} \mathrm{O}_{3}, \gamma-\mathrm{Fe}_{2} \mathrm{O}_{3}$, $\gamma$ - FeOOH, $\mathrm{Mn}_{2} \mathrm{O}_{3}, \mathrm{Mn}_{3} \mathrm{O}_{4}, \mathrm{MnS}, \mathrm{Ni}(\mathrm{OH})_{2}, \mathrm{Ni}_{2} \mathrm{O}_{3}, \mathrm{NiO}$, sulphides on the oxide - environment interface. The passive film was found to contain chromium oxide inner layer and the dissolution of iron through this caused the formation of oxides of iron namely $\alpha-\mathrm{Fe}_{2} \mathrm{O}_{3}$ and $\gamma-\mathrm{FeOOH}$. Higher oxides of manganese and nickel are also due to the dissolution through the film. Sulphates are reduced to sulphur chemically by the released protons from anodic polarization.

\section{REFERENCES}

[2] Lillie RS. Factors affecting transmission and recovery in the passive iron nerve model. J Gen Physiol 1925; 7: 473-507.

[3] Faraday M. Experimental Research in Electricity. Dover Publ: New York; Reprinted 1965; vol. 2: pp. 234-50.

[4] Uhlig HH, Wulff J. Trans AIME 1939; 135: 494.

[5] Blanc A, La Z. Electrochem 1900; 6: 472.

[6] Transtand L, Borgman CW. Some optical observation on the passivity of iron and steel in nitric and chromic acids. Trans Faraday Soc 1934; 30: 349-66.

[7] Hackerman N. Sorption, oxidation and passivity. Z Electrochem 1958; 62: 632-7.

[8] Brookes HC, Graham FJ, Bayles JW. Nucleation and growth of anodic films on stainless steel alloys I. Influence of minor alloying elements and applied potential on passive film growth. J App Electrochem 1990; 20(2): 223-30.

[9] Zhang BP etal. The corrosion behavior of amorphous Ni-Cr-19p alloys in hydrochloric acid. Corros Sci 1992; 33: 667-79.

[10] Scarberry RC, Gravir DL, Stephens CD. Alloying for corrosion control properties and benefits of alloy material. Mater protec 1967; 6: 54-7.

[11] Mazurkiewicz B. Anodic passivity of iron in sulphuric acid. Electrochim Act 1993; 38: 495-502.

[12] Haupt S, Strehblow HH. A combined surface analytical and electrochemical study of the formation of passive layers on $\mathrm{Fe} / \mathrm{Cr}$ alloys in $0.5 \mathrm{M} \mathrm{H}_{2} \mathrm{SO}_{4}$. Corros Sci 1995; 37: 43-54.

[13] Oblonsky LJ, Devine TM. A surface enhanced Raman spectroscopic study of the passive films formed in borate buffer on iron, nickel, chromium and stainless steel. Corros Sci 1995; 37: 17- 41.

[14] Amaral ST, Muller IL. Effect of silicate on passive films anodically formed on iron in alkaline solution as studied by electrochemical impedance spectroscopy. Corrosion 1999; 55: 17-23.

[15] Mansfeld F. Electrochemical impedance Spectroscopy (EIS) as a new tool for investigating methods of corrosion protection. Electrochem Act 1990; 35: 1533-44.

[16] Asami K, Hashimoto K. The X-ray photo-electron spectra of several oxides of iron and chromium. Corros Sci 1977; 17: 559-70.

[17] Moulder JF, Stickle WF, Sobel PE. Handbook of x-ray photo electron Spectroscopy. Perkin Elmer Corporation Eden Parouine; Minnesota: 1995.

[18] Brundle CR, Chuang TJ, Wandelt K. Core and valence level photoemission studies of iron oxide surfaces and the oxidation of iron. Surf Sci 1977; 68: 459-68.

[19] Ikemoto I, et al. X-ray photoelectron spectroscopic studies of $\mathrm{Cr}_{2} \mathrm{O}_{3}$ and some related chromium compounds. J Solid State Chem 1976; 17: 425-30.

[20] Lu YC, Clayton CR, Brooks AR. A bipolar model of the passivity of stainless steels-II. The influence of aqueous molybdate. Corros Sci 1989; 29: 863-80.

[21] Marcus P, Olefjord I, Oudar J. The influence of sulphur on the dissolution and the passivation of a nickel-iron alloy-II. Surface analysis by ESCA. Corros Sci 1984; 24: 269-78.

[22] Olefjord I, Elfstrom BO. The composition of the surface during passivation of stainless steel. Corrosion 1982; 38: 46-52.

[23] Jayalakshmi M, Muralidharan VS. Sulphur induced depassivation of transition metals in alkali solutions. Corros Rev 1994; 12: 35975.

[24] Jayalakshmi M, Muralidharan VS. Empirical and deterministic model of pitting corrosion - on overview. Corros Rev 1996; 14: 375-402.

[25] Jayalakshmi M, Muralidharan VS. Role of anions in the dissolution passivation and pitting of metals-a review. Corros Rev 2003; 21 : 327-47.

[26] Clayton CR, Doss K, Warren JB. Passivity of metals and semiconductors. Froment M, Ed. Elsevier Bombannes: 1983; 585-90.

[27] Asami K, Hashimoto K, Shimodaira S. An XPS study of the passivity of a series of iron-chromium alloys in sulphuric acid. Corros Sci 1978; 18: 151-60.

[28] Castle JE, Clayton CR. The use of in the x-ray photo-electron spectroscopy analyses of passive layers on stainless steel. Corros Sci 1977; 17: 7-26.

[29] Bockris JOM, Drazic D, Despic AR. The electrode kinetics of the deposition and dissolution of iron. Electrochim Act 1961; 4: 32561.

[30] Ogura KA. Dissolution-precipitation model for metal passivation. Electrochem Act 1980; 25: 335-9. 
[31] Hermas AA. Polarisation of low phosphorus AISI 304 Stainless steel in sulphuric acid containing arsenites. Br Corros J 1999; 34: $132-8$.

[32] Asami K, Hashimoto K, Shimodaira S. An ESCA study of the $\mathrm{Fe}^{2+} / \mathrm{Fe}^{3+}$ ratio in passive films on iron-chromium alloys. Corros Sci 1976; 1: 387-91.

[33] Sugimoto K, Sawada Y. The role of molybdenum additions to austenitic stainless steels in the inhibition of pitting in acid chloride solutions. Corros Sci 1977; 17: 425-45.

[34] Olefjord I, Brox B. Quantitative ESCA analysis of the passive state of an Fe-Cr-alloy and Fe-Cr-Mo alloy, ibid (26), Passivity of Metals and Semiconductors. Elsevier; Amsterdam: 1983; 561.
[35]

Schmuki P, Bohni H, Mansfeld F. A Photoelectrochemical investigation of passive films formed by alternating voltage passivation. J Electrochem Soc 1993; 140: L119.

[36] Yang MZ, Luo JL, Patchet BM. Correlation of hydrogen-facilitated pitting of AISI 304 stainless steel to semiconductivity of passive films. Thin Solid Films 1999; 354: 142-7.

[37] Duret-Thual C, Barrau F. Modification of passive films. Marcus P. Baroux B, Keddam M, Eds.; European Federation of Corrosion. Inst mater 1993; Vol. 12: pp. 176-88.

[38] Okamoto G. Passive film of 18.8 stainless steel structure and its function. Corros Sci 1973; 13: 471-89.

[39] Cigada A, Singaglia D, Re G, Borile F. Contribution to the interpretation of current maxima in the passivity range of Austenitic Stainless steel. Corrosion 1978; 34: 407-10.

Received: July 29, 2008

(C) Natarajan et al.; Licensee Bentham Open.

This is an open access article licensed under the terms of the Creative Commons Attribution Non-Commercial License (http: //creativecommons.org/licenses/by-nc/ $3.0 /$ ) which permits unrestricted, non-commercial use, distribution and reproduction in any medium, provided the work is properly cited. 